\title{
Editor's introduction to: a scholarly tribute to the 50th anniversary of the Western Regional Science Association
}

\author{
Janet E. Kohlhase
}

Published online: 18 January 2012

(C) Springer-Verlag 2012

\begin{abstract}
The paper provides an interpretive guide to the Special Issue commemorating the 50th anniversary of the Western Regional Science Association. The Special Issue contains 13 papers arranged into four groups (1) Perspectives on the Western Regional Science Association, (2) Assessment with a view to the future (3) Current topics-regional issues, and (4) Current topics — urban issues.
\end{abstract}

When I was asked to be the Guest Editor for a Special Issue celebrating the 50th anniversary of the Western Regional Science Association (WRSA), I jumped at the opportunity to work with my fellow regional science scholars around the world. I did not realize this small step would lead to a giant leap unto being a full editor within a few months. Truly, the Western Regional Science Association is a global organization and has been so for a long time, and I wanted to tap into that network. My goal here is to create an issue that has authors from around the world and a forward-looking emphasis, but that also gives respect to the past. This Special Issue has three components (1) history and prospective views of the Western Regional Science Association, (2) assessments of several of the broad research areas undertaken by regional scientists, and (3) show-casing some new ideas by current researchers in the field, some well-established and recent-PhDs from a wide range of countries.

The thirteen papers of this Special Issue are divided into four sections (1) Perspective on the Western Regional Science Association, (2) Assessment with a view to the future, (3) Current topics — regional issues, and (4) Current topics—urban issues. The authors come from around the world-from the United States, Japan, Australia, The Netherlands, Canada, and China. And the authors represent all stages of the academic ladder, from established eminent scholars to newly minted PhDs. Organizing

\footnotetext{
J. E. Kohlhase $(\varangle)$

Department of Economics, University of Houston, Houston, TX 77204-5019, USA

e-mail: jkohlhase@uh.edu
} 
and leading the Special Issue honoring 50 years of the WRSA has certainly highlighted the active intellectual development fostered by our association.

The first section of the Special Issue focuses on the development of the Western Regional Science Association, both in a historical sense and by an in-depth survey of current members. The article by Lay Gibson, Bob Monahan, and David Plane entitled "The first fifty years of the Western Regional Science Association: the makings of the WRSA brand as an academic organization" provides an anecdotal history of the Association since its birth in 1961. Authored by three long-term executive secretaries of the WRSA, the paper shows what is unique about the WRSA as compared to other academic societies and outlines how the Association has come to develop its distinctive WRSA brand: "the way academic life is supposed to be". The second paper in this section, "Documenting Regional Science exceptionalism: what's special about WRSA?" by Rachel Franklin and David Plane, attempts to measure that "specialness". They survey the WRSA membership in 2011, just before the 50th anniversary WRSA meeting. Besides providing a profile of the current membership, they find that two of the components generating the exceptionalism come from the interactions at the annual meetings of the WRSA. Members cite the high quality of the conference (papers are given substantially more time than typically occurs at other meetings) and the engaging collegiality among the attendees as important attributes of the WRSA.

The second general section of the 50th anniversary Special Issue contains four papers that critically assess the state of research in several regional science fields. These papers also suggest future scholarly research. These fields are not exhaustive of what has been covered by regional scientists but represent an important sampling of selected topics. Readers are referred to two other recent 50th anniversary Special Issues for other viewpoints on the past, current, and future research agendas in regional science, the Papers in Regional Science 50th anniversary Special Issue (Florax and Plane 2004), and the Journal of Regional Science 50th anniversary Special Issues (Duranton 2010).

The first paper in the assessment section is "Central Place Theory and its reemergence in regional science" by John Carruthers, Gordon Mulligan, and Mark Partridge. The authors provide a review of central place theory (CPT) from a multidisciplinary perspective-economics, geography, and planning. Following an in-depth review of traditional CPT, the authors provide insight into how CPT fits in with the newer perspectives used in the new economic geography (NEG). The authors argue that CPT and NEG are complementary approaches and that the area is ripe for future research in regional science. The second paper moves from a between-city perspective to analyzing economic structures within cities in, "Strangers in our midst: the usefulness of exploring polycentricity", by Ajay Agarwal, Genevieve Guliano, and Chris Redfearn. The authors provide a critical overview of theoretical and empirical papers on polycentric cities and maintain that multiple employment centers in these large cities provide important evidence that agglomeration economies operate at sub-metropolitan spatial scales. The third paper switches the focus to interregional issues by examining migration in "Migration and regional science: opportunities and challenges in a changing environment", by Bruce Newbold. He documents that both migration-themed and population-themed papers have been declining in their shares of publications in regional science journals. But, that fact creates challenges and 
opportunities for future migration research. Meeting one of the challenges suggested by Newbold is the paper "What about aging in regional science?" by David Plane. The paper is based on his 2010 Presidential address delivered in Denver at the 57th North American Meeting of the Regional Science Association International. He links aging research to migration research by discussing the importance of aging to changes in migration. Plane also discusses aging from two additional perspectives - the aging of the field of regional science as a major group of regional science practitioners has aged and how aging affects the spatial and temporal web of professional development of individual scholars at the personal level.

The third section contains three papers focusing on current research on regional issues. Masahisa Fujita and Nobuake Hamaguchi in "Japan and economic integration in East Asia: post-disaster scenario" provide, at a general level, a focus on how to interpret the current wave of regional integration in East Asia using the perspective of the agglomerative and dispersive forces from spatial economic theory. The authors demonstrate that East Asian economic integration is characterized by intraindustry vertical integration. Japan's role has been to specialize in high-tech intermediate goods production. But the sustainability of that role is called into question when considering a new source of dispersive forces, high-impact natural disasters - such as the Great East Japan Earthquake of March 11, 2011. The supply chain disruption risk and challenges for Japanese regional policies are discussed in the context of overall East Asian economic integration over time. The second paper in the regionalissues section is "High performers in complex spatial systems and networks: a selforganizing mapping approach", by Karima Kourtit, Daniel Aribas, and Peter Nijkamp. The authors examine the role of geography and firm characteristics on firm performance in the creative or high-tech sector using a new methodology, called selforganizing mapping (SOM). Using high-tech firms in the Netherlands in 2008 as the example, the authors find using regional differences that large firms tend to experience better business outcomes than do small or medium firms. The final paper in the regional section pays homage to an important innovator in regional science by developing a new spatial statistic, a measure of spatial variability, and is entitled "Local Spatial Heteroscedasticity (LOSH)" by Art Getis and Keith Ord. The new statistic is intended to identify statistically significant heterogeneity within local areas and can be used to identify transitional or border regions within a study area. The authors derive the new $H_{i}$-statistic, its variance, and provide three numerical examples of its application.

The final section of the Annals 50th anniversary Special Issue contains four papers focusing on current research on urban issues. The first paper, "The diffusion over time and space of energy efficiency in building", by Nils Kok, Marquise McGraw, and John Quigley, shows the unique perspective that regional science brings to combining environmental issues with the economics of space, by looking at "green issues" in commercial real estate in the United States. The authors analyze the determinants of the increasing share of commercial buildings to be certified for energy efficiency and sustainability across major US metropolitan areas over time. They use their findings to explain the considerable variability by metropolitan area in the shares certified by Energy Star and/or LEED. The second paper in the urban issues section is "Cities in Western Europe and the United States: do policy differences matter?" by Peter Gordon and Wendall Cox. The authors compare large cities in the two regions to assess the 
differences in the extent of urban-sprawl. The authors conclude that European cities are becoming more like American cities than vice versa, as evidenced by measures of outcomes and policy practices. The final two papers in the Special Issue show how the field is vigorously advancing, as we present the research of two WRSA award winners. The WRSA Springer-award-2011 winner is Ralph McLaughlin. The Springer prize is awarded to young scholars having less than five years of post- $\mathrm{PhD}$ experience. His paper looks at an understudied topic in urban economics, that of housing supply, and is titled "New housing supply in Australia: a comparison of dwelling types". Looking at housing markets in the six Australian state capital cities from 1983 to 2010, McLauglin provides a unique in the literature comparison of housing supply elasticities for multi-family relative to single-family units. He finds that supply responses are greater (more price elastic) for multi-family dwellings, but also more sluggish, by 4-8 quarters. The WRSA Tiebout award winner at the 2011 WRSA meetings is Pengyu Zhu. The Tiebout prize is awarded to the best graduate student paper presented at the annual WRSA meetings. Zhu analyzes a long-standing but until now unanswered question in urban research: Are telecommuting and personal travel substitutes or complements? Using data from two national household travel surveys, Zhu finds that telecommuting is complementary to personal travel, whether it is for work trips or total non-work trips.

Acknowledgments During my work on this Special Issue, I benefited from the advice of many people. I would like to especially thank Maureen Kilkenny and David Plane for their advice and help through the dark hours of organizing such issues. Steven Craig provided much needed cheer-leading and critical commentary too. I would also like to thank all the referees, most of whom are members of the Western Regional Science Association, for insightful comments on these papers in a timely manner. And of course a special debt of gratitude goes to the authors for their individual perspectives on the dynamic topics in regional science; again many are on the Boards of the journal or the Association or are members of the WRSA.

\section{References}

Duranton G (2010) Introduction: the Journal of Regional Science at 50: looking forward to the next 50 years. J Reg Sci 50(1):1-3

Florax RJGM, Plane DA (2004) Introducing the brightest of dawns: regional science in "Papers". Papers Reg Sci 83:5-29 